\title{
Evaluation of the antibacterial activity on strains responsible for diarrhoea; antioxidant and cytotoxic activities in vitro of the leaves and trunk bark of Vernonia conferta Benth (Asteraceae)
}

\author{
Ivan Cédric Mvondo Ozela 1,2, Patrick Yamen Mbopi 1, ${ }^{*}$, Herve Narcisse Bayaga 2, Pierre Réne Kwetche \\ Fotsing ${ }^{3}$, Jean Jacques Tchouani ${ }^{3}$ and Joseph Ngoupayo ${ }^{2}$ \\ ${ }^{1}$ Laboratory of Pharmacognosy; Université des Montagnes, B.P. 208 Bangangté; Cameroon. \\ 2 Laboratory of Pharmacognosy and Pharmaceutical Chemistry; Faculty of Medicine and Biomedical Sciences, University \\ of Yaoundé I, B.P. 1364 Yaoundé; Cameroon. \\ ${ }^{3}$ Laboratory of Microbiology; Université des Montagnes, B.P. 208 Bangangté; Cameroon.
}

GSC Biological and Pharmaceutical Sciences, 2021, 17(01), 041-051

Publication history: Received on 28 August 2021; revised on 03 October 2021; accepted on 05 October 2021

Article DOI: https://doi.org/10.30574/gscbps.2021.17.1.0294

\begin{abstract}
The high incidence of infectious diseases and the emergence of resistance to modern drugs are current public health concerns. This situation leads to the search for alternatives via medicinal plants. The objective of this study was to assess the properties of Vernonia conferta. We performed an experimental study. The plant material consisted of the leaves and trunk bark of $V$. conferta. The extraction was carried out by maceration using aqueous and hydro-ethanolic solvents, followed by phytochemical screening of the extracts. An evaluation of the antibacterial potential was carried out by the micro-dilution method and was followed by the evaluation of the antioxidant properties (DPPH and FRAP test) and cytotoxicity (resazurin staining) of the extracts. The E2 and E4 extracts exhibited better extraction yields. The phytochemical screening noted the presence of families of compounds in common (polyphenols, tannins and quinones) and those which are different. The hydro-ethanolic extracts exhibited antibacterial activity on the strains of interest with MICs varying from 2 to $32 \mathrm{mg} / \mathrm{mL}$ with a possibility of synergistic action between the compounds. The evaluation of the antioxidant properties showed that the extracts E1, E3 and E4 showed better properties with $\mathrm{IC}_{50}=25.1 \pm 0.410$; $2.456 \pm 0.002 ; 2.363 \pm 0.015 \mu \mathrm{g} / \mathrm{mL}$ respectively according to the tested method. The extracts showed their noncytotoxicity with $\mathrm{CC}_{50}>1000 \mu \mathrm{g} / \mathrm{mL}$. The activities of hydro-ethanolic extracts of $V$. conferta suggest that the latter would be a potential raw material for the production of improved traditional medicines.
\end{abstract}

Keywords: Vernonia conferta; Antibacterial activity; Antioxidant; Cytotoxic

\section{Introduction}

It is now well known that radicals play a fundamental role in several diseases. The biochemical damage they cause to cells and tissues has been implicated in several pathological disorders in humans and animals, including inflammatory and infectious diseases $[1,2,3,4]$. Infections due to pathogenic microorganisms represent a real public health problem [5]. According to a WHO report, they are the cause of 50\% of deaths in tropical countries and, $90 \%$ of these are the work of bacteria [6]. Among these infectious diseases of bacterial origin, diarrheal diseases are presented as one of the most fatal (1.8 million deaths / year), behind AIDS (2.9 million deaths / year), respiratory diseases (3.8 million deaths / year) and cardiovascular disease (over 16 million deaths / year) [7,8] and were ranked third on the ranking of the world's deadliest diseases and second in children under five, with 525,000 deaths per year. an [9]. In modern medicine, the management of bacterial diarrhea is essentially based on antibiotic therapy [10]. However, the high cost of this

\footnotetext{
* Corresponding author: Mbopi Yamen Patrick

Laboratory of Pharmacognosy; Université des Montagnes, B.P. 208 Bangangté; Cameroon.

Copyright ( $(2021$ Author(s) retain the copyright of this article. This article is published under the terms of the Creative Commons Attribution Liscense 4.0.
} 
treatment, the abusive use leading to the emergence of multiple resistance, and the limited access to quality health care force people in developing countries to resort to traditional medicine for their care. essential [11, 12]. Indeed, the WHO estimates that $80 \%$ of the populations in Africa use medicinal plants for their health problems [13]. Plants contain natural molecules that have been shown to have biological activities to decrease the damaging effect of free radicals [14]. Therefore, the discovery of new antimicrobial agents from plants that also target low toxicity free radicals can be used in herbal medicine [15]. Among these plants we find Vernonia conferta Benth from the Asteraceae family, a tree found in several countries whose leaves and bark are used in the form of maceration or decoction in traditional medicine to prevent infection of wounds, treatment of diarrhea, jaundice, intestinal and urogenital diseases, upset stomach and as an anthelmintic [16]. This present study was carried out in the perspective of studying the phytochemical composition and the antibacterial, antioxidant and cytotoxic properties from extracts of leaves and trunk bark of $V$. conferta.

\section{Material and methods}

\subsection{Collection of plant materials}

The plant material has been consisted of the leaves and bark of Vernonia conferta harvested on the morning of April 23, 2021 in the village Kalla II near Nkolbisson, in Yaoundé region of central Cameroon. The identification was carried out at the National Herbarium of Cameroon at number: 50342 / HNC. Our samples have been dried out of the sun at room temperature for 21 days, then sprayed with a three-phase VINCO ${ }^{\circledR}$ Model Y2-132S1-2.

\subsection{Microorganisms}

For the evaluation of the antibacterial potential of our extracts, six reference bacterial strains stored in a cool place have been used: Shigella flexneri (NR 518), Salmonella enteritidis (NR 13555), Staphylococcus aureus Methicillin resistant (ATCC 33591), Staphylococcus aureus (ATCC 43300), Salmonella typhi CPC (Centre Pasteur du Cameroun), Escherichia coli (ATCC 25922).

\subsection{Extraction}

The extraction was carried out according to the method described by Bagre et al. (2011) [17] with some modifications .Two hundred and fifty grams (250g) of powder from leaves and bark have been weighed using a KERN@ PLS balance (range: $0.01 \mathrm{~g}-4200 \mathrm{~g}$ ) and macerated with $2.5 \mathrm{~L}$ of an ethanol-water mixture (70:30) firstly and 3L of distilled water secondly for 48 hours, then filtered through Whatman paper No 3 paper. The filtrates have been concentrated and dried in a rotavapor (Rotavapor® BUCHI R-201) under reduced pressure at $40^{\circ} \mathrm{C}$ to obtain the dry extracts which have been conditioned and stored at $4^{\circ} \mathrm{C}$ for further study.

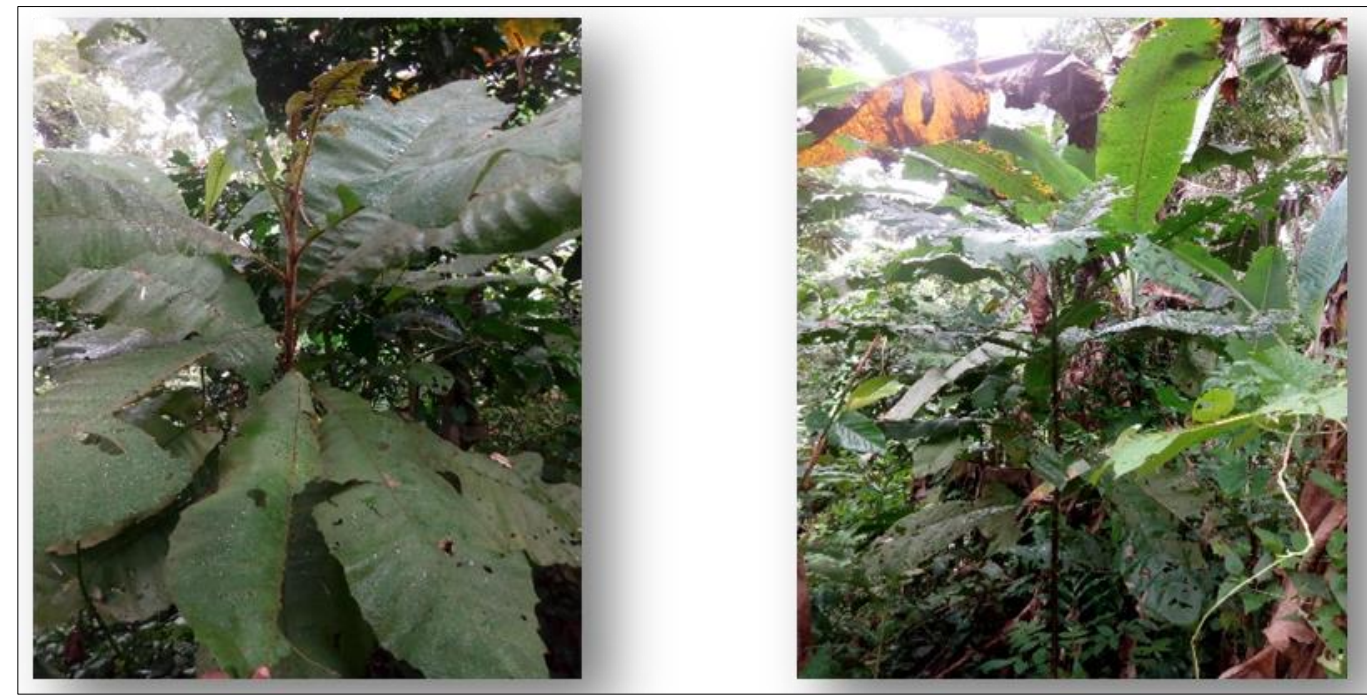

Figure 1 leaves (left) and whole plant (right) of Vernonia conferta 
The extraction yield (R) was calculated according to the following formula:

$$
R=\frac{(\text { mass of raw extract })}{\text { mass of powder }} \times 100
$$

\subsection{Phytochemical screening}

The crude extracts thus obtained were subject to the identification by precipitation reactions and staining according to the methodology of the phytochemical screening performed by respective conventional reactions $[18,19]$

Table 1 Usual methods of phytochemical screening

\begin{tabular}{|c|c|}
\hline Secondary metabolite & Reagent of identification \\
\hline Polyphenols & $\mathrm{FeCl}_{3}$ solution to $10 \%$ \\
\hline Flavonoids & Ethanol, $\mathrm{HCl}$, magnesium shavings \\
\hline Catechic tannin & $\mathrm{HCl}$ - Formalin \\
\hline Gallic tannin & $\mathrm{FeCl}_{3}$ solution to $2 \%$ \\
\hline Saponins & Foam index \\
\hline Coumarins & $\mathrm{NaOH}$, distilled water, UV lamp 254nm \\
\hline Anthocyanin & $\mathrm{HCl}, \mathrm{NH}_{4} \mathrm{OH}$ \\
\hline Alkaloids & $\mathrm{H}_{2} \mathrm{SO}_{4}$, Mayer /Dragendorff reagent \\
\hline Terpenoids and Steroids & Methanol, $\mathrm{CHCl}_{3}, \mathrm{H}_{2} \mathrm{SO}_{4}$, acetic anhydride \\
\hline Quinones & $\mathrm{H}_{2} \mathrm{SO}_{4}$ \\
\hline
\end{tabular}

\subsection{Antibacterial evaluation}

\subsubsection{Preparation of extract and standard solutions}

Plant extracts solutions have been prepared at a concentration of $100 \mathrm{mg} / \mathrm{mL}$. and Ciprofloxacin standard has been prepared in the same conditions at a concentration of $1 \mathrm{mg} / \mathrm{mL}$. The dissolving solvent is sterile distilled water.

\subsubsection{Bacterial inoculums preparation}

An aseptic condition for each bacterial strain, the bacteria have been subcultured on Muller-Hinton-Agar agars in kneading dishes, by the streak method, then incubated at $37^{\circ} \mathrm{C}$ for 24 hours to obtain young colonies used for the preparation of the bacterial inoculum.

From the 24 hours colonies, 1 to 3 colonies were picked using a platinum loop and introduced into 2 to $3 \mathrm{~mL}$ of sterile physiological water, to obtain turbidity similar to that of point 0.5 on the McFarland scale, corresponding to a variant concentration between $10^{6}$ and $10^{8}$ Colonial Forming Units / $\mathrm{mL}$.

\subsubsection{Determination of minimum inhibitory concentrations (MIC)}

The tests have been carried out in triplicate in sterile 96 -well microplates. Indeed, $72 \mu \mathrm{L}$ of MHB culture medium have been introduced in the first wells and $100 \mu \mathrm{L}$ in the rest of the wells of the plate. Then, $128 \mu \mathrm{L}$ of a sterile solution of each extract at the concentration of $100 \mathrm{mg} / \mathrm{mL}$ have been taken and introduced in the corresponding wells, followed by a series of dilutions of geometric reason of order 2 . Finally, $100 \mu \mathrm{L}$ of bacterial suspension at the concentration of $10^{6}$ cells / $\mathrm{mL}$ have been distributed in the test wells and those of the negative control. The concentrations of extracts and Ciprofloxacin in the wells ranged from $32 \mathrm{mg} / \mathrm{mL}$ to $1 \mathrm{mg} / \mathrm{mL}$ and from $1.95 \mu \mathrm{g} / \mathrm{mL}$ to $0.153 \mu \mathrm{g} / \mathrm{mL}$ respectively and the final concentration of the inoculum in each well was $5 \times 10^{5}$ cells. / mL. The sterility control has been constituted only of the culture medium. The positive control was constituted of the culture medium, inoculum and ciprofloxacin. The microplates have been covered and then incubated at $37^{\circ} \mathrm{C}$ for 24 hours. At the end of the incubation period, $20 \mu \mathrm{L}$ of a freshly prepared resazurin solution $(0.15 \mathrm{mg} / \mathrm{mL})$ have been added to all wells and the plates have been incubated 
in the same conditions for 30 minutes. The smallest concentration at which no change in color from blue to pink was observed corresponding to an absence of visible growth of the bacteria was considered to be MIC [20].

\subsubsection{Determination of minimum bactericidal concentrations (MBC)}

The evaluation of this parameter has been carried out by transplanting in liquid medium of the preparations from the plates used to determine the MIC. After incubation of the plates, $25 \mu \mathrm{L}$ have been taken from the wells corresponding to the MIC then transferred to the wells of another previously prepared plate containing $175 \mu \mathrm{L}$ of MHB. Thereby, the quantities of extracts contained in these different wells have been diluted 8 times in order to eliminate the inhibitory effect of the extract tested. The plates have been covered and incubated at $37^{\circ} \mathrm{C}$ for 48 hours. The tests have been carried out in triplicate. At the end of the incubation time, $20 \mu \mathrm{l}$ of resazurin have been added to each well and the plates reincubated at $37^{\circ} \mathrm{C}$ for $30 \mathrm{~min}$ and the smallest concentration of an extract showing no bacterial growth marked by the no-change in color of the resazurin (blue) was considered to be the bactericidal concentration of the extract [21]

\subsection{Antioxidant activity assessment}

\subsubsection{DPPH assay}

The determination of the antioxidant power of our extracts has been carried out using the DPPH radical according to the method previously described by Dieng et al. (2015) [22]. 0.02\% ethanolic solution of DPPH has been prepared. Then to $25 \mu \mathrm{L}$ of each solution of the extracts, has been added $75 \mu \mathrm{L}$ of the DPPH solution. All the extracts as well as the positive control (gallic acid) have been tested at different concentrations $(500 ; 250 ; 125 ; 62.5 ; 31.25 ; 15.62 ; 7.81 \mu \mathrm{g} /$ $\mathrm{mL}$ ).

Absorbance has been measured at $517 \mathrm{~nm}$ after incubation in the dark for $30 \mathrm{~min}$. The tests were carried out in triplicate. The antioxidant activity linked to the scavenging effect of the $\mathrm{DPPH}^{-}$radical has been expressed as a percentage inhibition (PI) using the following formula.

$$
(\mathrm{PI})=\frac{\text { Absorbance control }- \text { Absorbance sample }}{\text { Absorbance control }} \times 100
$$

\subsubsection{FRAP assay (Ferric Reducing Antioxidant Power Assay)}

The evaluation of the antioxidant power of our extracts has been then carried out by the Fe3+ reduction method previously described by Gohari al. (2011) [23]. To $25 \mu \mathrm{L}$ of each solution of the extracts at different concentrations, has been added $25 \mu \mathrm{L}$ of an iron (III) chloride solution at $1.2 \mathrm{mg} / \mathrm{mL}$. After 15 minutes of incubation in the dark, $50 \mu \mathrm{L}$ of the $0.2 \%$ orthophenantroline solution have been added and the optical density of the contents of the wells has been read at $505 \mathrm{~nm}$ with a plate reader (TECAN M200) after a second incubation of $15 \mathrm{~min}$. All the extracts as well as the positive control (gallic acid) have been tested at different concentrations $(500 ; 250 ; 125 ; 62.5 ; 31.25 ; 15.62 ; 15.62 ; 7.81$; $3.90 \mu \mathrm{g} / \mathrm{mL}$ ). The tests were carried out in triplicate.

\subsection{Cytotoxicity assay}

The evaluation of the cytotoxicity of our extracts has been evaluated according to the method described by Bowling et al. (2012) [24]. The Vero cell line (ATCC CRL 1586) from the normal kidney of the African green monkey has been maintained in complete modified Dulbecco Eagle medium supplemented with $10 \%$ fetal bovine serum, $0.2 \%$ sodium bicarbonate $(\mathrm{w} / \mathrm{v})$ with a combination penicillin-streptomycin $1 \%(\mathrm{v} / \mathrm{v})$. The cells have been maintained at $37{ }^{\circ} \mathrm{C}$ for 72 hours in a $5 \% \mathrm{CO}_{2}$ incubator, the medium has been renewed every $72 \mathrm{~h}$ and the cell density has been monitored under a reverse fluorescence microscope Etaluma ${ }^{\circledR} 520$ until the formation. of a monolayer. The confluent culture (nearly 90\%) has been mixed with a solution of trypsin (0.05\% Trypsin-EDTA), then centrifuged at $1800 \mathrm{rpm}$ for $5 \mathrm{~min}$ and the resulting pellet has been resuspended in the culture medium. A cell with a density of 10,000 cells per well in a $100 \mu \mathrm{L}$ suspension has been seeded on 96 -well plates and incubated for 24 hours at $5 \% \mathrm{CO}_{2}$ and $37^{\circ} \mathrm{C}$. to reach $90 \%$ confluence. $10 \mu \mathrm{L}$ of the extracts and of the control have been added after 24 hours at a starting concentration of 500 $\mu \mathrm{g} / \mathrm{ml}$. Positive control (Podophyllotoxin) has been added at a concentration of $20 \mu \mathrm{M}$. Subsequently, $10 \mu \mathrm{L}$ of Resazurin solution ( $0.15 \mathrm{mg} / \mathrm{mL}$ in sterile PBS) have been added to all the wells and incubated for an additional 4 hours in the same conditions. Fluorescence has been read using a Magelan Infinite M200(Tecan) Multiwell Plate Fluorescence Reader at excitation and emission wavelengths of 530 and $590 \mathrm{~nm}$ respectively. 


\subsection{Data analysis}

Every experiment has been repeated three times. The obtained data have been analysed by GraphPad Prism 5.0 software and subjected to analysis of variance (ANOVA). Statistical significance was set at $P<0.05$. All the values have been expressed as mean \pm standard deviation.

\section{Results}

\subsection{Extraction efficiency}

For the determination of the yields, the present work has led to obtaining the values for each of the extracts. Figure 2 shows the details relating to this starting operation.

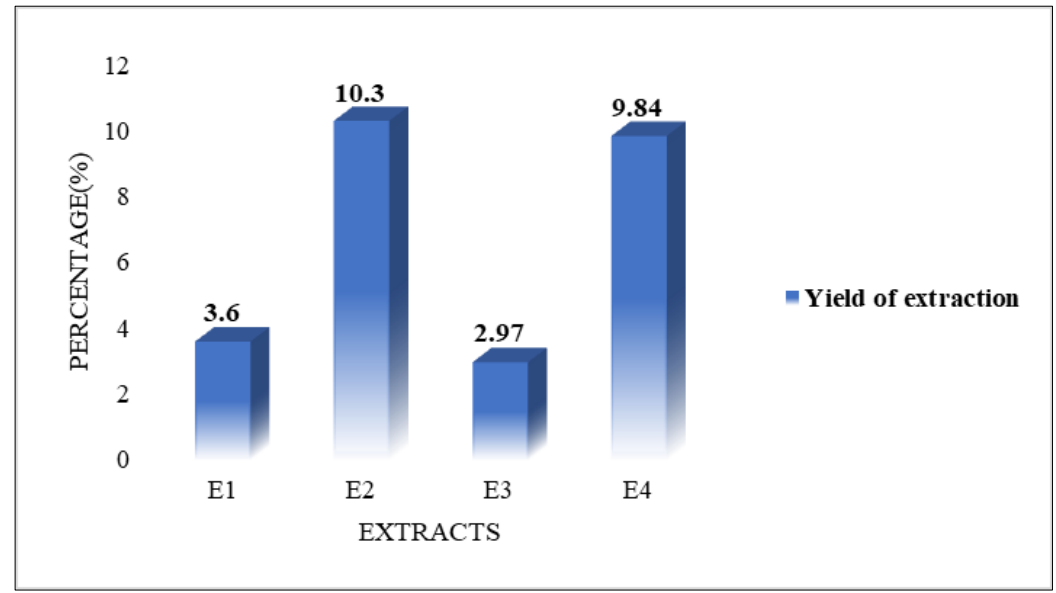

E1: Aqueous extract from the barks of $V$. conferta; E2: Aqueous extract from the leaves of $V$. conferta; E3: Hydroethanolic extract from the barks of $V$. conferta; E4: Hydroethanolic extract from the leaves of $V$. conferta;

Figure 2 Extraction yield of the different extracts

Figure 2 shows us that the extraction yields have been better with the aqueous and hydro-ethanolic maceration of the leaves of $V$. conferta (10.30 and $9.84 \%$ respectively).

\subsection{Phytochemical screening}

Phytochemical analysis of secondary metabolites tested in the different extracts, allowed us to obtain the results recorded in the Table 2.

Table 2 Results of phytochemical analysis

\begin{tabular}{|l|c|c|c|c|}
\hline Secondary metabolites & E1 & E2 & E3 & E4 \\
\hline Polyphenols & + & + & + & + \\
\hline Tannins & + & + & + & + \\
\hline Quinones & + & + & + & + \\
\hline Coumarins & + & + & + & + \\
\hline Anthocyanin & - & - & - & - \\
\hline Saponins & - & - & - & - \\
\hline Steroids & - & - & + & + \\
\hline Alkaloids & - & - & + & + \\
\hline Flavonoids & - & + & - & + \\
\hline Terpenoids & - & - & + & + \\
\hline
\end{tabular}

E1: Aqueous extract from the barks of $V$. conferta; E2: Aqueous extract from the leaves of $V$. conferta; E3: Hydroethanolic extract from the barks of $V$. conferta; E4: Hydroethanolic extract from the leaves of $V$. conferta; +: present; -: absent 
The results presented in Table 2 have shown firstly that the polyphenols, tannins, coumarins and quinones are present in all the extracts. Then the flavonoids are found only in the leaves. However, steroids, terpenoids and alkaloids are present only in hydroethanolic extracts. Finally, we note the absence of anthocyanins and saponins in all extracts.

\subsection{Antibacterial evaluation}

The results of the antibacterial activity of our extracts have been recorded in Table 3 .

Table 3 Minimum Inhibitory Concentration and Minimum Bactericidal Concentration of extracts

\begin{tabular}{|l|c|c|c|c|c|c|c|c|c|c|}
\hline & \multicolumn{2}{|c|}{ SF } & \multicolumn{2}{c|}{ EC } & \multicolumn{2}{c|}{ ST } & \multicolumn{2}{c|}{ SA } & \multicolumn{2}{c|}{ SAMR } \\
\hline extract & $\begin{array}{c}\text { MIC } \\
(\mathbf{m g} / \mathbf{m L})\end{array}$ & $\begin{array}{c}\text { MBC } \\
(\mathbf{m g} / \mathbf{m L})\end{array}$ & $\begin{array}{c}\text { MIC } \\
(\mathbf{m g} / \mathbf{m L})\end{array}$ & $\begin{array}{c}\text { MBC } \\
(\mathbf{m g} / \mathbf{m L})\end{array}$ & $\begin{array}{c}\text { MIC } \\
(\mathbf{m g} / \mathbf{m L})\end{array}$ & $\begin{array}{c}\text { MBC } \\
(\mathbf{m g} / \mathbf{m L})\end{array}$ & $\begin{array}{c}\text { MIC } \\
(\mathbf{m g} / \mathbf{m L})\end{array}$ & $\begin{array}{c}\text { MBC } \\
(\mathbf{m g} / \mathbf{m L})\end{array}$ & $\begin{array}{c}\text { MIC } \\
(\mathbf{m g} / \mathbf{m L})\end{array}$ & $\begin{array}{c}\text { MBC } \\
(\mathbf{m g} / \mathbf{m L})\end{array}$ \\
\hline E1 & $\mathrm{Nd}$ & $\mathrm{Nd}$ & $\mathrm{Nd}$ & $\mathrm{Nd}$ & $\mathrm{Nd}$ & $\mathrm{Nd}$ & $\mathrm{Nd}$ & $\mathrm{Nd}$ & $\mathrm{Nd}$ & $\mathrm{Nd}$ \\
\hline E2 & $\mathrm{Nd}$ & $\mathrm{Nd}$ & $\mathrm{Nd}$ & $\mathrm{Nd}$ & $\mathrm{Nd}$ & $\mathrm{Nd}$ & $\mathrm{Nd}$ & $\mathrm{Nd}$ & $\mathrm{Nd}$ & $\mathrm{Nd}$ \\
\hline E3 & $>32$ & $>32$ & 32 & $>32$ & 32 & $>32$ & 16 & 32 & 4 & 16 \\
\hline E4 & 32 & $>32$ & 32 & $>32$ & $>32$ & $>32$ & 16 & $>32$ & 2 & 8 \\
\hline CP & 0.062 & 0.031 & 0.031 & 0.062 & 0.01 & 0.062 & 0.031 & 0.125 & 0.015 & 0.031 \\
\hline
\end{tabular}

E1: Aqueous extract from the barks of $V$. conferta; E2: Aqueous extract from the leaves of $V$. conferta; E3: Hydroethanolic extract from the barks of $V$. conferta; E4: Hydroethanolic extract from the leaves of V. conferta; SF : Shigella flexneri NR 518, SE : Salmonella enteritidis NR 13555, SAMR : Staphylococcus aureus Methicillin resistant ATCC 33591, SA : Staphylococcus aureus ATCC 43300, ST : Salmonella typhi CPC (Centre Pasteur du Cameroun), EC : Escherichia coli ATCC 25922, CP : Ciprofloxacin; Nd: Not determined

The analysis of Table 3 allowed us to observe that certain strains have been sensitive (S. aureus and SAMR) than others. Only the hydroethanolic extracts had MIC values between 2 and $32 \mathrm{mg} / \mathrm{mL}$.

\subsection{Antioxidant assay}

\subsubsection{DPPH assay}

The percentages of inhibition of the extracts and the gallic acid are presented in Figure 3.

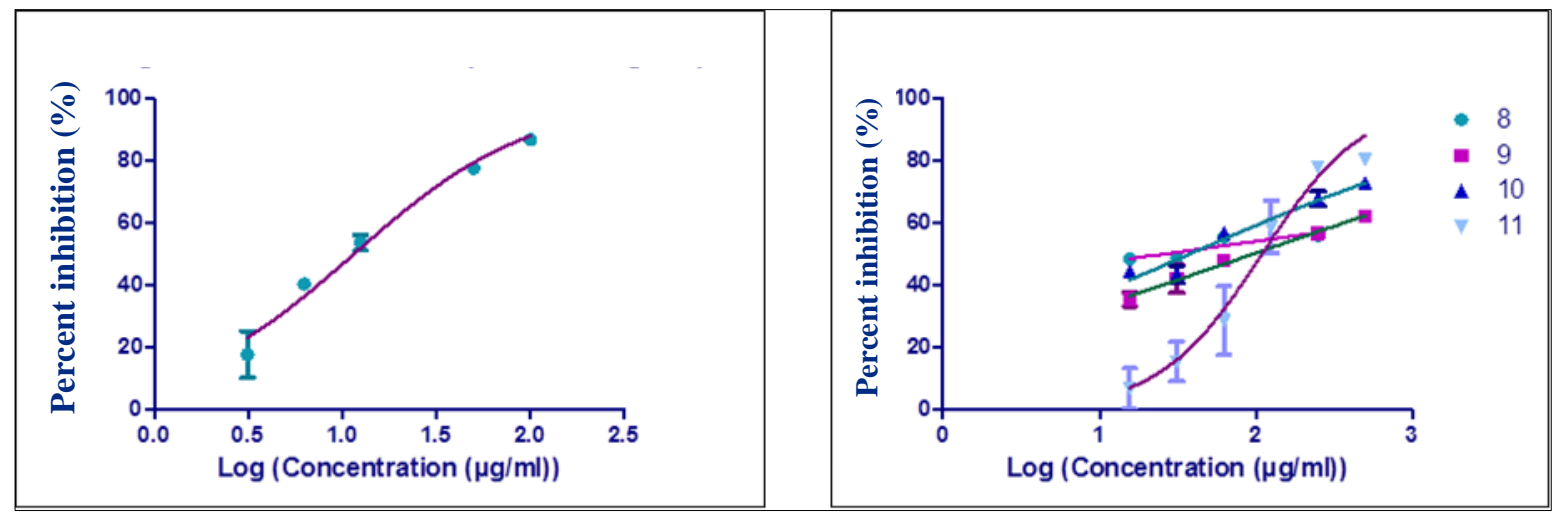

8: Aqueous extract from the barks of $V$. conferta, 9: Aqueous extract from the leaves of $V$. conferta, 10: Hydroethanolic extract from the barks of $V$. conferta, 11: Hydroethanolic extract from the leaves of $V$. conferta

Figure 3 Percent inhibition of gallic acid (left) and extracts (right)

Figure 3 shows the logarithmic concentrations at which the DPPH radical has been trapped.

At different concentrations, the aqueous extract of $V$. conferta bark powder showed the best percent inhibition. To better compare the antioxidant potential of the extracts, the $\mathrm{IC}_{50}$ valuea have been determined (Table 4 ). The aqueous extract of $V$. conferta bark powder showed the lowest IC50 (Table 4). 
Table 4 IC $_{50}$ of different extracts and positive control

\begin{tabular}{|l|l|}
\hline \multicolumn{2}{|c|}{ DPPH } \\
\hline Extract & IC $_{50}(\mu \mathrm{g} / \mathrm{mL})$ \\
\hline E1 & $25.1 \pm 0.410^{\mathrm{b}}$ \\
\hline E2 & $99.51 \pm 14.842^{\mathrm{d}}$ \\
\hline E3 & $37.5 \pm 0.240 \mathrm{c}^{\mathrm{e}}$ \\
\hline E4 & $106.5 \pm 8.909$ \\
\hline Gallic acid & $11.41 \pm 0.134^{\mathrm{a}}$ \\
\hline
\end{tabular}

E1: Aqueous extract from the barks of $V$. conferta; E2: Aqueous extract from the leaves of $V$. conferta; E3: Hydroethanolic extract from the barks of $V$. conferta; E4: Hydroethanolic extract from the leaves of $V$. conferta

Different letters indicated statistically significant differences between means according to Duncan's new multiple range test $(\mathrm{P}<0.05)$.

\subsubsection{FRAP assay (Ferric Reducing Antioxidant Power Assay)}

The percentages of inhibition of the extracts and the gallic acid are presented in Figure 4.

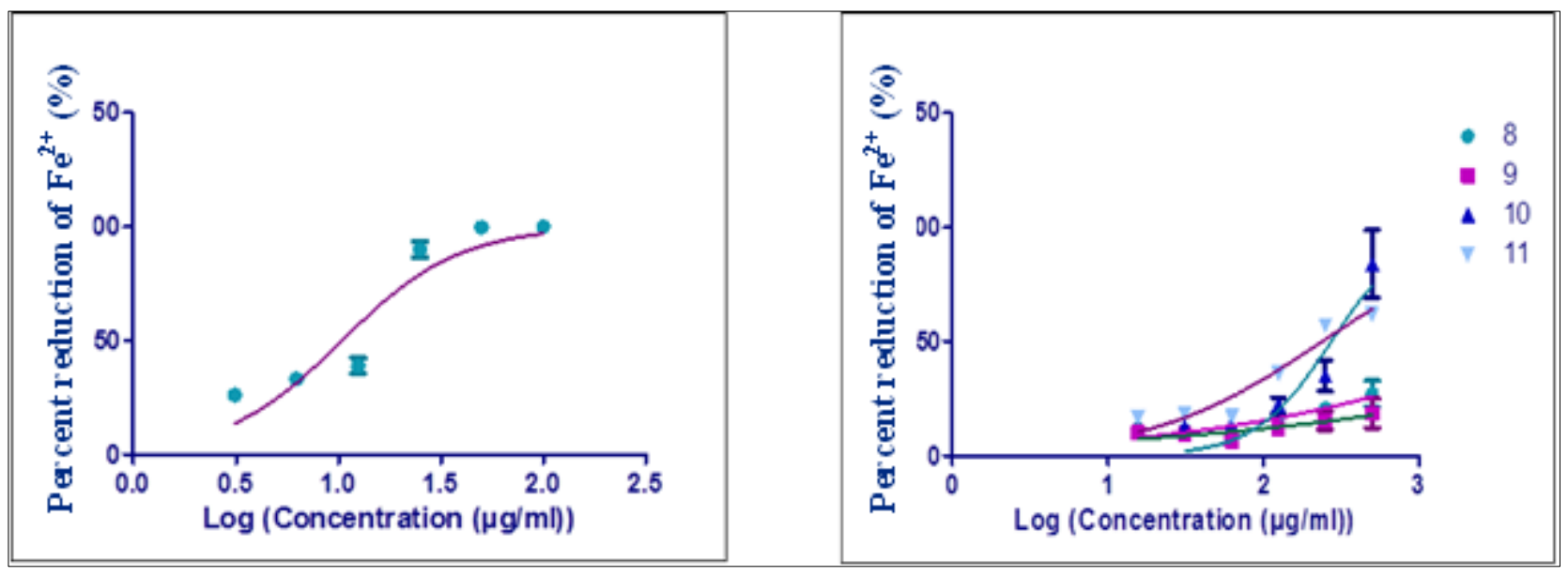

8: Aqueous extract from the barks of $V$. conferta, 9: Aqueous extract from the leaves of $V$. conferta, 10: Hydroethanolic extract from the barks of $V$. conferta, 11: Hydroethanolic extract from the leaves of $V$. conferta

Figure 4 Percent inhibition of gallic acid (left) and extracts (right)

Table 5 IC50 of different extracts and positive control

\begin{tabular}{|l|l|}
\hline \multicolumn{2}{|c|}{ FRAP } \\
\hline Extract & IC $_{50}(\mu \mathrm{g} / \mathrm{mL})$ \\
\hline E1 & $>500^{\mathrm{c}}$ \\
\hline E2 & $>500^{\mathrm{c}}$ \\
\hline E3 & $2.456 \pm 0.002^{\mathrm{b}}$ \\
\hline E4 & $2.363 \pm 0.015^{\mathrm{b}}$ \\
\hline Gallic acid & $10.46 \pm 0.722^{\mathrm{a}}$ \\
\hline
\end{tabular}

E1: Aqueous extract from the barks of $V$. conferta; E2: Aqueous extract from the leaves of $V$. conferta; E3: Hydroethanolic extract from the barks of $V$. conferta; E4: Hydroethanolic extract from the leaves of $V$. conferta

Different letters indicated statistically significant differences between means according to Duncan's new multiple range test $(\mathrm{P}<0.05)$. 
Figure 4 shows the logarithmic concentrations at which $\mathrm{Fe}^{3+}$ has been reduced. At different concentrations, the hydroethanolic extract of the bark powder and leaves of $V$. conferta showed the best percentages of inhibition. To better compare the antioxidant potential of the extracts, the IC 50 values have been determined. The hydroethanolic extracts of the bark powder and leaves of $V$. conferta showed the lowest ic50 (Table 5).

\subsection{Cytotoxicity assay}

The cytotoxicity activity of our extracts has been evaluated according to the cytotoxicity criteria of crude extracts as established by the American National Cancer Institute (NCI) stipulating that the $\mathrm{CC}_{50}$ of the extract $<30 \mu \mathrm{g} / \mathrm{mL}$ demonstrates a cytotoxic extract [25].

In this study, our different extracts tested showed no cytotoxic effect on VERO cells because all the extracts had an $\mathrm{CC}_{50}>$ $30 \mu \mathrm{g} / \mathrm{mL}$ (Table 6).

Table 6 Extract cytotoxicity results

\begin{tabular}{|l|c|}
\hline Extract & $\begin{array}{c}\mathbf{C C}_{\mathbf{5 0}}(\boldsymbol{\mu g} / \mathbf{m L}) \\
\text { In Vero cells }\end{array}$ \\
\hline E1 & $>1000$ \\
\hline E2 & $>1000$ \\
\hline E3 & $>1000$ \\
\hline E4 & $>1000$ \\
\hline
\end{tabular}

E1: Aqueous extract from the barks of $V$. conferta; E2: Aqueous extract from the leaves of $V$. conferta; E3: Hydroethanolic extract from the barks of $V$. conferta; E4: Hydroethanolic extract from the leaves of V. conferta; $\mathbf{C C}_{50}$ : Cytotoxic Concentration 50

\section{Discussion}

The present work aimed to evaluate the antibacterial, antioxidant and cytotoxic activities of powder extracts from the leaves and bark of Vernonia conferta. The results obtained showed that the best extraction yields have been obtained by aqueous $(10.30 \%)$ and hydroethanolic (9.84\%) maceration of the leaf powders and weak with the bark powder. This result can initially be justified by the nature of the solvent used. Indeed, maceration with hydroethanolic and aqueous solvents would make it possible to extract compounds of high and medium polarity [26]. Secondly, by the concentration of molecules in the parts of a plant. Indeed, studies have shown that the leaves are the seat of photosynthesis and therefore of synthesis and accumulation of molecules [27]. This result has been also found on species of the same genus, in particular on the bark of Vernonia cinerea where a low yield (6.08\%) has been reported [28].

Phytochemical screening on all the extracts showed that they had in common four (polyphenols, tannins, coumarins and quinones) of the ten secondary metabolites sought in this work. Two extracts (hydroethanolic extracts from the bark and the leaves) showed the presence of terpenoids, alkaloids and steroids. It's to highlight that the saponins and anthocyanins were absent in all the extracts (Table 2). In view of the above, the hydroethanolic extract of the leaves has been the richest in secondary metabolites, which justifies its high yield. These results are similar to the work carried out on the species V. ambigua, V. blumeoides and V. oocephata where alkaloids, flavonoids, tannins, steroids and terpenes have been found in ethanolic extracts of the leaves [29] and on the same species of our study where it was shown the presence of alkaloids, steroids and terpenes [30]. These different bioactive compounds present in each of the extracts could attribute different biological activities to the extracts, in particular the antioxidant activity [31; 32] and antibacterial [32; 33].

The evaluation of the antibacterial potential of our extracts showed that the aqueous extracts (leaves and bark) at the concentrations used did not inhibit the bacterial strains used in this work, unlike the hydroethanolic extracts. According to these results, the hydroethanolic extracts showed a more pronounced antibacterial potential on the Staphylococcus aureus Methicillin resistant strain with MICs ranging from 4 to $16 \mathrm{mg} / \mathrm{mL}$ for the hydroethanolic extract of the bark and a MIC ranging from 2 to $8 \mathrm{mg} / \mathrm{mL}$ for the hydroethanolic extract of the leaves (Table 3); this would show that our two extracts have more activity on gram-positive bacteria. Works on the species V. amigdalina have shown that hydroethanolic extracts have a more pronounced inhibition than aqueous ones on bacterial strains [34]. However, the aqueous extracts not having shown any activity, would suggest that the antibacterial potential of our extracts would not be attributed to the polyphenols but to the compounds present in the hydroethanolic extracts (alkaloids, steroids and 
terpenes) (Table 2) which have already had to demonstrate their antibacterial properties [35, 36, 37]. nevertheless, it should be noted that the activity of the hydroethanolic extract of the leaves has been slightly more pronounced than that of the hydroethanolic extract of the bark. This could be due to the presence of flavonoids in the hydroethanolic extract of the leaves which would have had a synergistic action with the other constituents [38]. However, according to a classification of the activity of plant extracts according to the value of their MIC revealed by Toam et al. (2016) [39], our extracts used in this study are weakly active on all bacteria. Indeed, for this author, the activity of an extract is significant if the MIC is less than $500 \mu \mathrm{g} / \mathrm{mL}$. It is said to be moderate if the MIC is between 500 and $1500 \mu \mathrm{g} / \mathrm{mL}$ and low if the MIC is greater than $1500 \mu \mathrm{g} / \mathrm{mL}$ [39]. It would therefore be interesting to study the antibacterial potential of the essential oil of this species

The use of a hydroalcoholic and aqueous solvent made it possible to extract from the leaves, bark and stems of our samples (bark and leaves of $V$. conferta) polar compounds such as polyphenols [40] which are part of the main components of plants with antioxidant activity [41]. However, the results of the antioxidant activity carried out on all the extracts have showed that the hydroethanolic extracts of the leaves and bark of $V$. conferta have showed better antioxidant activities on the FRAP test (Table 5); and the aqueous extract of the bark of $V$. conferta has showed better antioxidant activity on the DPPH test (Table 4). It would have been interesting to assess the polyphenol content of our different extracts. Indeed, these results show that the antioxidant activity of our extracts would not only be attributed to the polyphenols present but also to other metabolites found, in particular alkaloids, steroids and terpenoids found in the hydroethanolic extract of the bark (Table 1). These results have been found on other species of the same genus, in particular on the leaves of $V$. cinerea and $V$. amygdalina where the hydroethanolic extract of the leaves of $V$. cinerea had a more interesting activity than that of the extract. aqueous $V$. amygdalina leaves on the DPPH test [42,43].

\section{Conclusion}

The hydroethanolic maceration of the leaves and bark of $V$. conferta is an interesting technique for the production of the high value of active extracts. The result of this study pointed out that antibacterial, antioxidant activities and noncytotoxic exhaled by in vitro hydroethanolic extracts due to the presence of bioactive compounds. Further research is necessary to identify of the therapeutic molecules and even to study the effectiveness of its essential oil to enable the production of "Médicaments Traditionnels Améliorés".

\section{Compliance with ethical standards}

\section{Acknowledgments}

The author express appreciation to the teams of the Pharmacognosy and pharmaceutical Chemistry laboratory and then the Phytobiochemistry laboratory where this study took place.

\section{Disclosure of conflict of interest}

The authors declare that there are no conflicting interests.

\section{References}

[1] Cheng HY, Lin TC, Yu KH, Yang CM, Lin CC. Antioxidant and free radical scavenging activities of Terminalia chebula. Biol Pharm Bull. 2003; 26:1331-5.

[2] Ellmain-Wojtaszek M, Kruczynski Z, Kasprzak J. Investigation of the free radical scavenging activity of Ginkgo Biloba L. leaves. Fitoterapia. 2003; 74: 1-6.

[3] Govindarajan R, Vijayakumar M, Pushpangadan P. Antioxidant approach to disease management and the role of Rasayana herbs of Ayureda. J Ethnopharmacol. 2005; 99: 165-78.

[4] Alviano DS, Alviano CS. Plants extracts: Search for new alternatives to treat microbial diseases. Curr Pharm Biotechnol 2009; 10(1): 106-21

[5] Eswarappa SM. Location of pathogenic bacteria during persistent infections: Insight from an analysis using game theory. PLoS ONE 2009; 4(4): e5383.

[6] WHO. WHO lifts the veil on the world's leading causes of death and disability: 2000-2019 [Internet]. Genève : OMS. 2020. 
[7] Eniko EA. Communicable diseables. Paris : Atlas de l’Intégration Régionale. 2008.

[8] Nguendo Y, Salem G, Thouez J-P. Health risks related to excreta sanitation methods in Yaounde, Cameroon. Nat Sci Soc. 16(1) : 3-12.

[9] Dosso M, Coulibaly M, Kadio A. Place of bacterial diarrhea in developing countries. Bull la Soc Pathol Exot. 1998; 91(5): 402-5.

[10] Ngo T. Antidiarrhoeal, antimicrobial and antioxidant properties of two Cameroonian medicinal plants: Trilepisium madagascariens DC. Leuwen Berg (Moraceae) and Entada abyssinica Steud. EXA. Rich. (Mimosaceae). [PhD. Animal Physiology]. Dschang: Université de Dschang. 2011.

[11] Monnet DL. Consumption of antibiotics and bacterial resistance. Ann Fr Anesth Reanim. 2000; 19: 409-17.

[12] World Healh Organiyation. WHO strategies for traditional medicine 2002-2005. Highlights of the year 2000 in term of essential drugs and policies pharmaceutical. Genève: OMS; 2002.

[13] Dibong S, Mpondo E, Ngoye A, Kwin M. Medicinal plants used by the Bassa populations of the Douala region in Cameroon. Int J Biol Chem Sci. 2011; 5(3): 1105-17.

[14] Baratta MT, Dorman HJD, Deans SG, Biondi DM, Ruberto G. Chemical composition, antimicrobial and antioxidant activity of laurel, sage, rosemary, oregano and coriander essential oil. J Essent Oil Res. 1998; 10(6): 618-27.

[15] Kuete V, Efferth T. Cameroonian medicinal plants: pharmacology and derived natural products.Front Pharmacol. 2010; 1: 123-12.

[16] Ajibesin KK, Ekpo BA, Bala DN, Essien EE, Adesanya SA. Ethnobotanical survey of Akwa Ibom State of Nigeria. J Ethnopharmacol. 2007; 115(3): 387-408.

[17] Bagre I, Bahi C, Ouattara K, Guede NZ, Djaman AJ, Coulibaly A, et al. Botanical study and exploration of the antifungal activity of Morinda morindoides (Baker) Milne-Redh. On the in vitro growth of Cryptococcus neoformans. Phytotherapie. 2011; 9(2): 136-41.

[18] Ndouguet JC, Mbopi YP, Fotsing KPR, Ngalemo NCB, Pahane MM, Tekam JM. Antibacterial potential of the flavonoids from the fruits of Voacanga africana Stapf and Tabernaemontana contorta Stapf on diarrheagenic bacteria: A comparative study between the crude extracts and their fractions. J Pharmacogn Phytochemi. 2021; 10(5): 57-64.

[19] Bruneton J. Pharmacognosy, phytochemistry, medicinals plants. 3ème Ed. Paris : Edition Technique et Documentation-Lavoisier, Paris. 1999.

[20] Teh CH, Nazni WA, Nurulhusna AH, Norazah A, Lee HL. Determination of antibacterial activity and minimum inhibitory concentration of larval extract of fly via resazurin-based turbidometric assay. BMC Microbiol. 2017; 17: 36-43.

[21] Ngoupayo J, Assonfack FRM, Matchawe C, Djiele NP, Ndelo J. Evaluation of the antimicrobial activity of tannin extracted from the barks of Erythrophleum guineensis (Caesalpiniaceae). J Pharmacogn Phytochemi. 2016; 5(4): 287-91.

[22] Dieng SIM, FalL AD, Diatta-Badji K, Sarr A, Sene M, Sene M, et al. Evaluation of the antioxidant activity of hydroethanolic extracts from the leaves of Piliostigma thonningii Schumach. Int. J Biol. Chem Sci. 2017; 11(2): 768-76.

[23] Gohari AR, Hajimehdipoor H, Saeidnia S, Ajani Y, Hadjiakhoodi A. Antioxidant activity of some medicinal species using FRAP assay. J Med Plant. 2011; 10(37): 54-60.

[24] Bowling T, Mercer L, Don R, Jacobs R, Nare B. Application of a resazurin-based highthroughput screening assay for the identification and progression of new treatments for human African trypanosomiasis. Int J Parasitol Drugs Drug Resist. 2012; 262-70.

[25] Itharat A, Houghton J P, Eno-Amooquaye E, Burke P J, Sampson J H, Raman A. In vitro cytotoxic traditionally to treat cancer. J Ethnopharmacol. 2004; 90: 33-8.

[26] Wichtl M, Anton R. Therapeutic plants : Tradition, pratique officinale, science et thérapeutique. 2eme Ed. Paris : Tec et Doc. 2003.

[27] Pinto ACQ, Ramos VHV, Rodrigues AA. "Formação do Pomar". In: Gaviola, Produção. Brasilia: Embrapa Informação Tecnológica. 2003. 
[28] Singh A, Bhandari A, Khatri A, Kumawat I, Saharan V. A pharmacognostical study of Vernonia cinerea Less (Asteraceae) and evaluation of anti-inflammatory and antibacterial activities of stem. Egypt Pharm J. 2014; 13(2): 104-12.

[29] Aliyu AB, Musa AM, Abdullahi MS, Hamisu I, Oyewale A. Phytochemecal screening and antibacterial activities of Vernonia ambigua, Vernonia blumeoides and Vernonia oocephala (Asteraceae). Acta Pol Pharm. 2011; 68(1): 6773.

[30] Mballa RN, Wokam MN, Nguidjoe EM, Kamga HG, Wouessidjewe D. Antibaterial activity of a recipe based on the barks of Petersianthus Macrocarpus, Vernonia Conferta and Carica Papaya, Traditionally used to treat chronic wounds. Heal Sci Dis. 2020 ; 21(10) : 49-53.

[31] Raupp D da S, Rodrigues E, Rockenbach II, Carbonar A, Campos PF de, Borsato AV, et al. Effect of processing on antioxidant potential and total phenolics content in beet (Beta vulgaris L.). Food Sci Technol. 2011; 31(3): 68893.

[32] Chitra Jain, Shivani Khatana, Rekha Vijayvergia. Bioactivity of secondary metabolites of various plants: A review. Int J Pharm Sci Res. 2019; 10(2): 494-504.

[33] Ngoupayo J, Assonfack FRM, Matchawe C, Djiele NP, Ndelo J. Evaluation of the antimicrobial activity of tannin extracted from the barks of Erythrophleum guineensis (Caesalpiniaceae). J Pharmacogn Phytochemi. 2016; 5(4): 287-91.

[34] Ghamba P, Balla H, Goje L., Halidu A, Dauda M. In vitro antimicrobial activities of Vernonia amygdalina on selected clinical isolates. Int J Curr Microbiol App Sci. 2014; 3(4): 1103-13.

[35] Karou D, Savadogo A, Canini A, Yameogo S, Montesano C, Simpore J, Colizzi V, Traore SA. Antibacterial activity of alkaloids from Sida acuta. Afr J Biotechnol. 2005; 4(12): 1452-7.

[36] Doğan A, Otlu S, Çelebi Ö, Kiliçle AP, Sağlam GA, Doğan CAN, Mutlu N. An investigation of antibacterial effects of steroids. Turk J Vet Anim Sci. 2017; 41: 302-5.

[37] Guimarães CA, Meireles LM, Lemos MF, Guimarães CCM, Endringer CD, Fronza M, Scherer R. Antibacterial Activity of Terpenes and Terpenoids present in the Essential Oils. Molecules. 2019; 24: 2471-82.

[38] Zainul AZ, Nur DM, Maizatul HO, Muhammad T, Rusliza B. Methanol extract of Muntingia calabura leaves attenuates $\mathrm{CCl}_{4}$-induced liver injury:possible synergistic action of flavonoids and volatile bioactive compounds on endogenous defence system. Pharma Biol. 2019; 57(1): 335-44.

[39] Toam KAL, Fotsing KPR, Dongmo GS, Louokdom SJ, Mbieleu JD, Dimo T. Antibacterial activity of extract from the stem bark of Alafia multiflora (Stapf) on extended beta-lactamasa-positive multi-drug resistant hospital bacteria. World J Pharm Pharm Sci. 2016; 5(10): 1267-82.

[40] Mahmoudi S, Mahmoudi KN. Study of the extraction of phenolic compounds from different parts of the flower artichoke (Cynara scolymus). Nat Technol. $2013 ; 9: 35-40$.

[41] Dieng M, Fall AD, Diatta K, Diatta W, Bassene E. Determination of polyphenols and antioxidant activity of leaves and male inflorescences of Borassus aethiopum, Mart. (Arecaceae). Int J Biol Chem Sci. 2015; 9(1): $1067-71$.

[42] Alara OR, Abdurahman NH, Ukaegbu CI. Soxhlet extraction of phenolic compounds from Vernonia cinereal leaves and its antioxidant activity. J Appl Res Med Aromat Plants. 2018; 11: 2-17.

[43] Ho WY, Liang WS, Yeap SK, Beh BK, Yousr AHN, Alittheen NB. In vitro and in vivo antioxidant activity of Vernonia amygdalina water extract. Afr J Biotechnol. 2012; 11(17): 4090-4. 